\title{
Containment of Coronavirus Disease-2019 Pandemic in India: Need to Adopt a Concerted and Multisectoral Response
}

\author{
Saurabh RamBihariLal Shrivastava, Prateek Saurabh Shrivastava ${ }^{1}$ \\ Member of the Medical Education Unit and Institute Research Council, Department of Community Medicine, Shri Sathya Sai Medical College and Research Institute, Sri Balaji \\ Vidyapeeth - Deemed to be University, ${ }^{1}$ Department of Community Medicine, Shri Sathya Sai Medical College and Research Institute, Sri Balaji Vidyapeeth - Deemed to be \\ University, Ammapettai, Nellikuppam, Chengalpet District, Tamil Nadu, India
}

\section{Abstract}

The coronavirus disease-2019 (COVID-19) pandemic has threatened the progress made in the field of the health sector across the globe. From the Indian perspective, we have become the third most affected nation across the globe and the trends of the novel infection continues to worsen further. All these estimates are a clear marker of the fact that we have not been up to the mark in terms of both preparedness activities as well as the public health response to the infection. Amidst all these developments, there is an indispensable need that we have to divert our all our resources and adopt a multi-sectoral response for the effective containment of the infection with the active and concerted support of all the stakeholders. In conclusion, the COVID-19 cases in India has been increasing on an alarming note and it is the need of the hour to continue to improve our outbreak readiness and emergency response. Further, we cannot defeat the COVID-19 until we all are together in the battle against the novel infection and continue to support the Government in all their planned strategies.

Keywords: COVID-19 pandemic, India, preparedness

\section{INTRODUCTION}

The coronavirus disease-2019 (COVID-19) pandemic has threatened the progress made in the field of the health sector across the globe. ${ }^{[1,2]}$ This is clearly evident due to the fact that the pandemic has affected each and every individual and all the determinants of human lives directly or indirectly. ${ }^{[1,2]}$ From the epidemiological perspective, as on July 12, 2020, a cumulative total of 12,552,765 cases and 561,617 deaths have been reported worldwide, which amounts to a global case fatality rate of $4.47 \%$. ${ }^{[1]}$ Moreover, the disease has been reported across 216 nations and territories since its first detection in the Wuhan city of China.

\section{COVID-19 pandemic in India}

From the Indian perspective, after an initial gradual rise in the incidence of the disease, the daily incidence of the cases has immensely increased, with 28,637 cases being reported within a span of $24 \mathrm{~h}$ and thus taking the cumulative total to 849,553 cases. $^{[1]}$ At the same time, the disease has resulted in the death of 22,674 people owing to the development of disease-related complications. ${ }^{[1,3]}$ Even though community

\begin{tabular}{|l|l|}
\hline \multicolumn{2}{|c|}{ Access this article online } \\
\hline Quick Response Code: & Website: \\
\hline & www.ijrc.in \\
\hline
\end{tabular}

transmission of the disease has not yet been reported, it is worth noticing that India has become the third most affected nation across the globe and the trends of the novel infection continues to worsen further. ${ }^{[1-3]}$ Within the nation, the states of Maharashtra and Tamil Nadu and Union Territory of Delhi are currently the most affected ones.

As already stated above, in the initial period of the outbreak, the rise in the incidence of the reported cases was quite less and this was both due to the nationwide lockdown and also due to the laboratory testing capacity in the nation. ${ }^{[4]}$ However, with the relaxation of the lockdown in various parts of the

Address for correspondence: Dr. Saurabh RamBihariLal Shrivastava, Professor, Department of Community Medicine, Shri Sathya Sai Medical College and Research Institute, Sri Balaji Vidyapeeth (SBV) - Deemed to be University, Tiruporur - Guduvancherry Main Road, Ammapettai, Nellikuppam, Chengalpet District - 603 108, Tamil Nadu, India. E-mail: drshrishri2008@gmail.com

This is an open access journal, and articles are distributed under the terms of the Creative Commons Attribution-NonCommercial-ShareAlike 4.0 License, which allows others to remix, tweak, and build upon the work non-commercially, as long as appropriate credit is given and the new creations are licensed under the identical terms.

For reprints contact: WKHLRPMedknow_reprints@wolterskluwer.com

How to cite this article: Shrivastava SR, Shrivastava PS. Containment of coronavirus disease-2019 pandemic in India: Need to adopt a concerted and multisectoral response. Indian J Respir Care 2021;10:156-7.

Received: $20-03-2020$

Accepted: $30-08-2020$
Revised: 13-07-2020 Published: $31-01-2021$ 
nation, initiation of working in various sector (to support the economic growth of the nation and help the people from lower socioeconomic class), and improvement in the daily laboratory testing, there has been a significant increase in the daily incidence of the cases. ${ }^{[4]}$ All these estimates are clear markers of the fact that we have not been up to the mark in terms of both preparedness as well as the public health response to the infection. Even though some of the states or districts in the nation have been successful in reducing the trends of the disease, none of the individuals, families, or areas can be complacent till we have access to an effective drug or a prophylactic vaccine. ${ }^{[2,3]}$

\section{Need for a multisectoral response}

Amidst all these developments, there is an indispensable need that we have to divert all our resources and adopt a multisectoral response for the effective containment of the infection with the active and concerted support of all the stakeholders. ${ }^{[2-5]}$ The first and foremost thing will be to strengthen the diagnostic capacity and promote more and more detection of cases, so that further transmission of the infection can be averted at the earliest ${ }^{[5]}$ In addition, the health-care establishments and health sector have to precisely forecast the number of cases and thus improve the response both in terms of human resources, infrastructure, logistics required for the timely isolation, and management of the cases. ${ }^{[5]}$ Moreover, the practice of contact tracing has to be further strengthened and this has to be led by the community workers, as the health professionals are already overburdened with the caseload and rehabilitation. ${ }^{[6]}$

\section{Other recommended interventions}

Further, we need to improve the infection control measures at various points of entries and airports/trains/bus stands to avert the risk of initiation of a new chain of infection. However, none of the planned measures can deliver the desired results, unless they are well supported with the community interventions, which predominantly includes staying indoors preferably, avoiding social gatherings, use of infection prevention and control measures, and not spread rumors about the infection.
In addition, the public health authorities have to strengthen the risk communication activities. The Aarogya Setu app which has been launched by the government is a wonderful step. Finally, there is a significant need to extensively invest in the field of research to not only enhance the understanding about the disease, including its modes of transmission, but also to come out with a potential vaccine or a drug at the earliest. ${ }^{[2-5]}$

\section{ConcLusion}

In conclusion, the COVID-19 cases in India has been increasing on an alarming note and it is the need of the hour to continue to improve our outbreak readiness and emergency response. Further, we cannot defeat the COVID-19 until we all are together in the battle against the novel infection and continue to support the government in all their planned strategies.

\section{Financial support and sponsorship}

Nil.

\section{Conflicts of interest}

There are no conflicts of interest.

\section{RefEREnCES}

1. World Health Organization. Coronavirus disease 2019 (COVID-19) Situation Report - 174; 2020. Available from: https://www.who.int/ docs/default-source/coronaviruse/situation-reports/20200712-covid19-sitrep-174.pdf?sfvrsn=5d1c1b2c_2. [Last accessed on $2020 \mathrm{Jul} 13]$.

2. Kumar SU, Kumar DT, Christopher BP, Doss CGP. The Rise and Impact of COVID-19 in India. Front Med (Lausanne) 2020;7:250.

3. Pal R, Yadav U. COVID-19 pandemic in India: Present scenario and a steep climb ahead. J Prim Care Community Health 2020;11:2150132720939402.

4. Pai C, Bhaskar A, Rawoot V. Investigating the dynamics of COVID-19 pandemic in India under lockdown. Chaos Solitons Fractals 2020;138:109988.

5. World Health Organization. 2019 Novel Coronavirus (2019nCoV): Strategic preparedness and response plan. Geneva: WHO press; 2020. p. 1-20.

6. Shrivastava SR, Shrivastava PS. Corona virus disease 2019 pandemic: encouraging involvement of community workers in the active search of cases. MAMC J Med Sci 2020;6:39-40. 